\title{
ЭКОЛОГО-ОРНИТОЛОГИЧЕСКАЯ ХАРАКТЕРИСТИКА АЭРОПОРТА «ЧЕРЕМШАНКА» (АЭРОУЗЛА «КРАСНОЯРСК») В ЗИМНИЙ ПЕРИОД
}

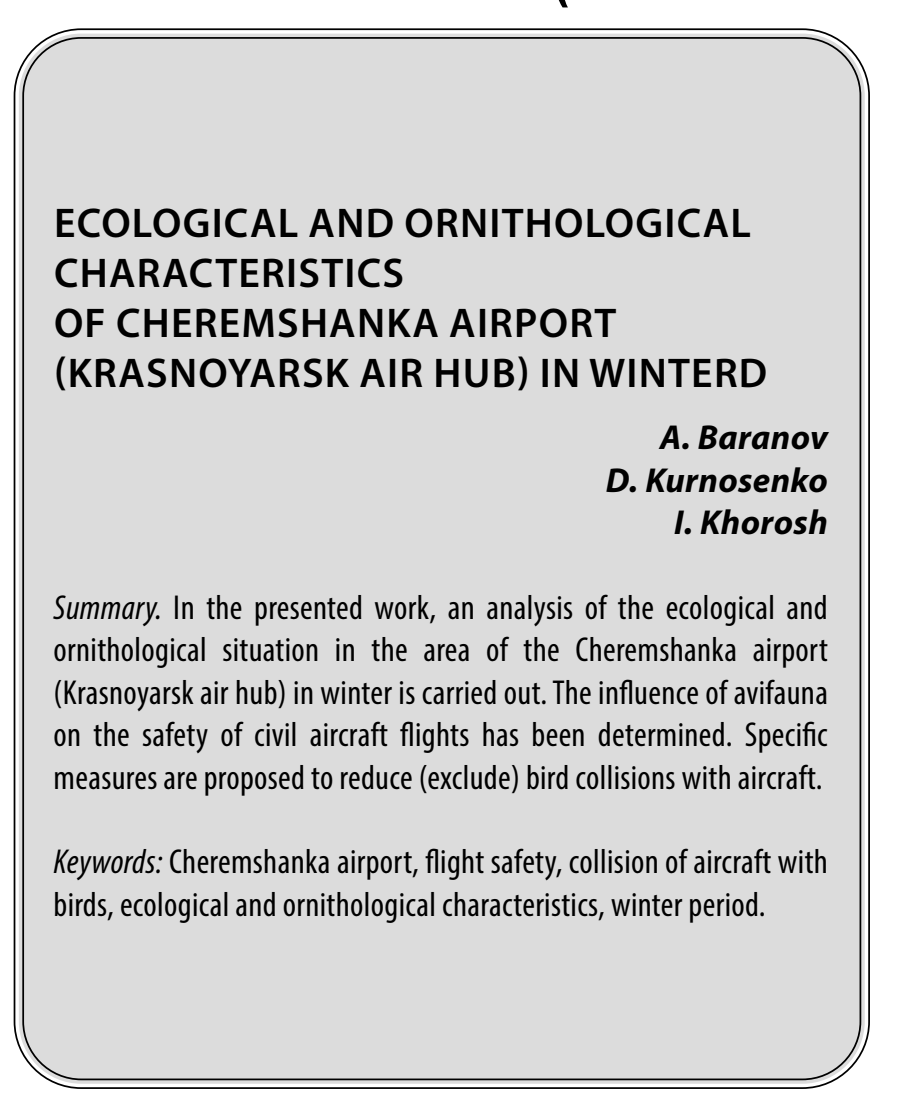

C толкновение с птицами (англ. bird strike) - термин, означающий столкновение в воздухе либо при передвижении по земной (водной) поверхности между летательным аппаратом и птицей (птицами). Является одним из важных факторов, способных в значительной мере воздействовать на безопасность полётов. Имеет большое значение. Так Международная организация гражданской авиации ежегодно регистрирует порядка 5400 столкновений воздушных судов с птицами [5].

\section{АктУа^ьнОсть исслеАования}

В гражданской авиации безопасность полётов занимает приоритетное место. Как уже было сказано выше, одним из факторов обеспечения безаварийной деятельности гражданской авиации является исключение, или уменьшение количества случаев столкновения самолётов (вертолётов) с птицами. В связи с этим проблема наличия точной эколого-орнитологической характеристики зоны вокруг конкретного аэропорта,
Баранов Александр Алексеевич Д.б.н., профессор, ФГБОУВО «Красноярский государственный педагогический университет им. В.П. Астафьева», г. Красноярска abaranov@kspu.ru

Курносенко Денис Валерьевич Аспирант, ФГБОУ ВО «Красноярский государственный педагогический университет им. В.П. Астафьева», г. Красноярска

kurnosenkodenis@mail.ru

Хорош Иван Алексеевич

К.т.н., дочент, ФГБОУ ВО «Красноярский государственный аграрный университет» khorth@mail.ru

Аннотация. В представленной работе проведен анализ эколого-орнитологической обстановки в районе аэропорта «Черемшанка» (аэроузла «Красноярск») в зимний период. Определено влияние авиафауны на безопасность полётов гражданских воздушных судов. Предложены конкретные меры для снижения (исключения) столкновения птиц с воздушными судами.

Ключевые слова: аэропорт «Черемшанка», безопасность полётов, столкновение воздушных судов с птицами, эколого-орнитологическая характеристика, зимний период.

(в нашем случае аэропорта «Черемшанка», аэроузла «Красноярск») и создание подробного орнитологического паспорта, а также научно обоснованные меры способные нивелировать угрозы, которые представляет орнитофауна для гражданских воздушных судов, представляется нам весьма актуальным.

К сожалению, приходится констатировать, что проводимые исследования в данной области, для аэродрома «Черемшанка», до настоящего времени являлись эпизодическими и, определённо требовали продолжения и систематизации.

Кроме того, актуальность исследования вызвана возможным ростом риска столкновений птиц с гражданскими воздушными судами, в связи с предполагаемым увеличением полётов (после снятия ограничений вызванных пандемией COVID-19), которое вытекает из развития всего аэроузла (в первую очередь введение в строй нового пассажирского терминала и строительства магистральной рулежной дорожки на всю длину взлетно-посадочной полосы (далее - ВПП) 
в международном аэропорту «Красноярск», который также входит в состав одноименного ауроузла).

\section{Цели и залачи \\ исслеАОвания}

Дать общую характеристику эколого-орнитологической обстановке зоны аэропорта «Черемшанка», аэроузла «Красноярск» в зимний период. Выяснить влияние птиц на безопасность полётов.

Для достижения поставленной цели, нами предусматривалось решение следующего ряда задач:

1. выявить какие виды птиц встречаются на территории 15 километровой зоны аэропорта «Черемшанка», аэроузла «Красноярск» в зимний период;

2. определить какие из выявленных видов птиц представляют наибольшую опасность для воздушных судов;

3. выявить имели ли место случаи столкновения птиц с воздушными судами в районе аэропорта «Черемшанка», аэроузла «Красноярск» в рассматриваемый период;

4. на основании проведенных исследований предложить комплекс мероприятий, направленных на орнитологическое обеспечение безопасности полётов для аэропорта «Черемшанка», аэроузла «Красноярск».

\section{Объект}

исслеАований

Территория 15 километровой зоны вокруг аэропорта «Черемшанка», аэроузла «Красноярск».

\section{Преммет исслеАований}

Влияние орнитологической обстановки на безопасность полётов для аэропорта «Черемшанка», аэроузла «Красноярск» в зимний период.

\section{Метолы}

Проведённое исследование осуществлялось общеизвестными аналитическими методами. Основными способами получения, обобщения, систематизации и интерпретации полученной информации и статистических данных были описательный метод, исторический метод, анализ и синтез.

\section{Метолика исслеАования}

Экспериментальные исследования проводились на территории 15 километровой зоны вокруг аэропорта «Черемшанка», аэроузла «Красноярск».
Для получения эколого-орнитологической характеристики, помимо видового анализ и выявления самолётоопасных видов птиц в процессе пешего осмотра, периодических осмотра с воздушных судов и осмотра местности с применением беспилотных летательных аппаратов (по предварительному согласованию с органами управления воздушным движением) применялся анонимный опрос лётного и инженерно-технического состава.

\section{Практическая значимость}

Проведенный нами комплекс исследований эколого-орнитологической обстановки зоны аэропорта «Черемшанка», аэроузла «Красноярск могут быть рекомендованы для использования в качестве исходного теоретического обоснования для выработки конкретных практических мер для обеспечения безопасности полётов в орнитологическом отношении для конкретного аэропорта в различные времена года (в данном случае в зимний период).

Аэропорт «Черемшанка» - региональный аэропорт краевого центра Красноярского края - города Красноярска. ВПП аэропорта «Черемшанка» расположена в 1700 метрах к северо-востоку от ВПП международного аэропорта «Красноярск».

Большинство видов птиц, обитающих в 15-и километровой зоне аэродрома «Черемшанка», как и на всей прочей территории Российской Федерации (и всего мира), обладают определённым потенциалом опасности для воздушных судов - различным для каждого из видов птиц.

Так согласно проводимым в разные годы в нашей стране орнитологическим исследованиям, дифференциация птиц по числу столкновений с воздушными судами выглядит следующим образом: по частоте столкновений с воздушными судами лидируют чайки - 35\% от общего числа зарегистрированных случаев. Чуть меньше около 17\%, приходится на долю воробьинообразных и стрижей - 17\%. Голуби становятся виновниками $16 \%$ столкновений с воздушными судами, на доли дневных хищных птиц и водоплавающих приходится по $10 \%$, а так называемых врановых - 7\% [4].

Сезонность в определении самолётоопасных видов также имеет значение [2].

Традиционно для набора условий нашей страны максимальной опасностью для полётов характеризовался июль - в среднем 26,5\% столкновений от общего их объёма, а в целом вторая половина лета - время присутствия в популяциях большого количества моло- 
дых птиц, не имеющих достаточного опыта, позволяющего в той или иной степени предотвращать опасные контакты с воздушными транспортными средствами [3].

В добавление к выше приведенному утверждению на основании исследований, проведенных с момента открытия аэропорта «Черемшанка» по 15 декабря 2018 года и анализа данных полученных в ходе опрос летного и технического состава, мы располагаем сведениями минимум о пяти незарегистрированных случаях столкновениях птиц с воздушными судами в районе аэропорта «Черемшанка» (при этом официально зарегистрированные случаи отсутствуют), которые произошли в теплое время года [1].

Таким образом в зимний период вероятность столкновения воздушного судна с птицами является маловероятной (но присутствующей).

Зимний состав авиафауны вокруг аэропорта «Черемшанка» начинает формироваться уже во второй половине октября и к середине декабря в окрестностях аэродрома остаются только зимующие виды птиц, а именно 22 вида: Бородатая неясыть, Длиннохвостая неясыть, Воробей домовый, Воробей полевой, Ворон, Гаичка буроголовая, Гаичка черноголовая, Дубонос обыкновенный, Дятел пестрый, Дятел седой, Черный дятел, Желна, Глухарь обыкновенный, Рябинник, Рябчик, Свиристель, Сизый голубь, Синица большая, Сорока, Снегирь обыкновенный, Черная ворона, Чернозобый дрозд (частично зимующий вид).

Опасность для воздушных судов представляют прежде всего виды, биотопически приуроченные к зоне аэропорта и его близлежащим окрестностям - черная ворона, сорока, полевой и домовый воробей. Также определенную опасность в этот период составляют стайные виды, встречающиеся только в холодное время года - большая синица, свиристель, рябинник и чернозобый дрозд. Три последних вида в поисках корма довольно часто пролетают через ВПП аэропорта, поскольку они связаны с плодово-ягодными насаждениями населенных пунктов, дачных и садовых участков.

Мы можем утверждать, что проблема обеспечения орнитологической безопасности полётов в районе аэ- ропорта существует и требует принятия практических шагов для её решения.

В качестве конкретных практических мер, целесообразно на территории аэропорта «Черемшанка», аэроузла «Красноярск» провести комплекс мероприятий для большего обеспечения безопасности полётов в орнитологическом отношении. Рекомендуется, помимо использования штатных пиротехнических средств отпугивания птиц (требующих контроля со стороны персонала), установить акустические и ультразвуковые отпугиватели, которые могут работать полностью автоматизировано.

\section{Выво $\triangle$}

1. Эколого-орнитологическая обстановка аэропорта «Черемшанка», аэроузла «Красноярск» в зимний период характеризуется наличием характерными для Восточной Сибири 22 видов оседлых и оседлокочующих птиц (всего в различные времена года на территории аэропорта встречаются 109 видов).

2. В целом в зимний период времени в районе аэропорта «Черемшанка», аэроузла «Красноярск» для воздушных судов вероятность столкновения с птицами крайне мала (но не исключена).

3. Из встречающихся на территории аэропорта «Черемшанка» видов птиц высокой степенью опасности для воздушных судов в зимний период обладают врановые и воробьинообразные.

4. На территории аэропорта «Черемшанка» и в его окрестностях необходимо провести мероприятия по устранению мест ночевок врановых и ликвидации несанкционированных свалок.

5. Непосредственно на территории аэропорта «Черемшанка» необходимо провести мероприятия для большего обеспечения безопасности полётов в орнитологическом отношении (помимо штатных пиротехнических средств, целесообразно установить акустические и ультразвуковые отпугиватели птиц).

6. Необходимо продолжить работы по уточнению эколого-орнитологическая обстановки аэропорта «Черемшанка», аэроузла «Красноярск», выявить и описать её составляющие в динамике.

\section{ЛИТЕРАТУРА}

1. К Курносенко Д.В. Эколого-орнитологическая характеристика аэропорта «Черемшанка» (аэроузла «Красноярск») и её влияние на безопасность полётов гражданских воздушных судов / Д.В. Курносенко, А.А. Баранов // Современная наука: актуальные проблемы теории и практики. Серия: Естественные и технические науки. 2019. № 4. С. 7-10.

2. Кухта А.Е. Концептуальные подходы к орнитологическому обеспечению безопасности полётов воздушных судов / А.Е. Кухта, Н.П. Большакова, А.В. Мацюра // Вестник Тувинского государственного университета. № 2 Естественные и сельскохозяйственные науки. 2017. № 2 (33). С. 96 -105. 
3. Рыжов С.К. Столкновения гражданских воздушных судов с птицами в России в 2008 г. Аналитические материалы / С.К. Рыжов // журнал «Авиатранспортное обозрение», г. Москва, № 102, 2009 г.

4. Шитов В.В. Птицы в авиации: агрессоры или жертвы? / В.В. Шитов // Журнал «Гражданская авиация», г. Москва, № 4 (812), 2012 г.

5. Эксперт: В год происходит более 5 тысяч столкновений самолетов с птицами. Российская газета [Электронный ресурc] // URL: https://rg.ru/2019/08/16/ reg-cfo/ekspert-v-god-proishodit-bolee-5-tysiach-stolknovenij-samoletov-s-pticami.html. (Дата обращения: 11.08.2021).

(с Баранов Александр Алексеевич ( abaranov@kspu.ru),

Курносенко Денис Валерьевич ( kurnosenkodenis@mail.ru),Хорош Иван Алексеевич ( khorth@mail.ru ).

Журнал «Современная наука: актуальные проблемы теории и практики»

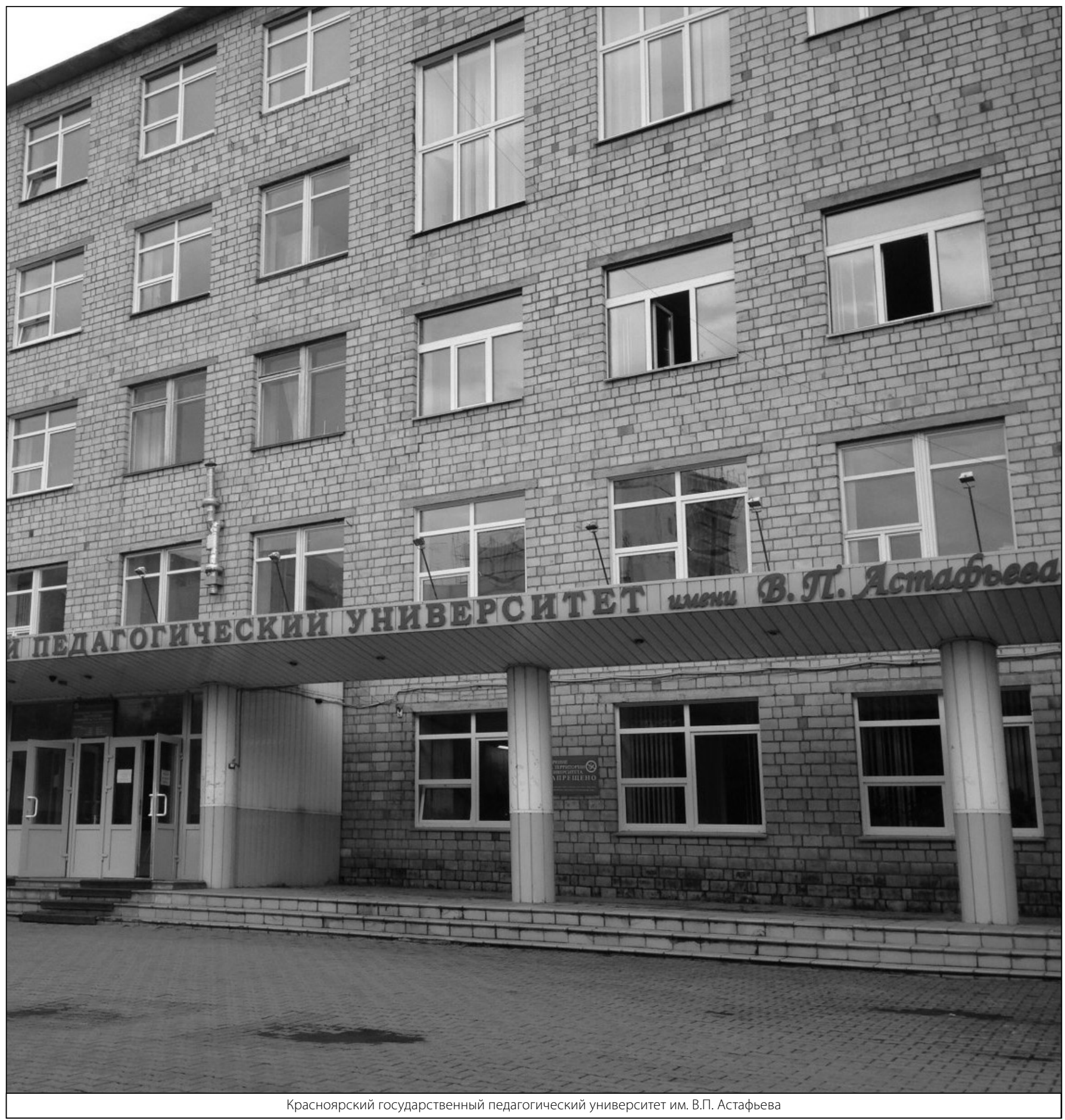

